\title{
Currency Board, Dollarisation or Flexible Exchange Rates for Emerging Economies? Reflections on Argentina
}

\begin{abstract}
Since the 1990s many emerging countries have adopted a fixed exchange-rate peg vis-à-vis a reserve currency in order to cope with economic imialances such as buoyant inflation, high unemployment or staggering economic growth. However, after a period of economic stabilisation and prosperity, overheating effects showed up in several countries that were often coupled with difficulties in the banking and/or the real estate sector. Sticking with a fixed peg, the likelihood of a currency crisis increased.

The case of Argentina shows that even with a currency board it is difficult to restore confidence if a crisis has already been developing for several years. This article presents an economic analysis of the Argentina crisis.
\end{abstract}

\begin{abstract}
$M$ any emerging countries have adopted the strategy of fostering economic growth by encouraging the influx of foreign capital. Under globalised financial markets where capital is highly mobile and can be transferred from one place to another with small transaction costs, developing countries have to create favourable conditions for investors in order to attract foreign funds. The enhanced competition in financial markets is mainly due to deregulation, the suspension of capital restrictions, the creation of derivatives and technological progress in telecommunication and computer systems.
\end{abstract}

Emerging countries usually possess comparative cost advantages that arise from cheap and welltrained labour, abundant resources of minerals and land. In order to promote economic development, foreign capital is imperative for the financing of investments. Such countries were compelled to liberalise their markets, allowing foreign investors to acquire substantial shares in local enterprises, and permitting foreign banks and financial corporations to open branches, grant credits and to deal freely in local equity and obligations markets without discrimination. In order to gain the confidence of investors, emerging countries had to pursue a disciplined policy that would stabilise the economy and the value of money.

* Professor of Economics, University of Fribourg, Switzerland.
These countries usually experienced periods of high rates of inflation and unemployment, imbalances in the government sector and external deficits. To stabilise the economy countries often chose to peg the domestic currency to a reserve currency. Fixed exchange rates help a country to discipline its economic policy and to restore the confidence of investors.

\section{The Danger of Currency Crises}

In many emerging countries such measures were used to conquer unstable situations and to foster economic growth. Mexico, the East Asian Countries, Russia and Brazil used different forms of pegs to solve economic problems before falling into banking and currency crises in the 1990s.' What are the reasons that such events occur? Why is a peg condemned to fail even if initial benefits seem to justify it?

The story is usually as follows: given the peg and the liberalisation of financial markets, huge (shortterm) capital flows will enter an emerging country because domestic interest rates are larger than

\footnotetext{
' Cf. G. Aschinger: Währungs- und Finanzkrisen - Entstehung, Analyse und Beurteilung aktueller Krisen, Verlag F. Vahlen, Munich 2001; G. Aschinger: Why do Currency Crises Arise and How Could They be Avoided?, in: Intereconomics, Vol. 36, May/June 2001, pp.152-159; and G. Aschinger: An Economic Analysis of the East Asia Crisis, in: Intereconomics, Vol. 33, March/April 1998 pp.55-63.
} 
foreign ones and the perspectives of high economic growth attract foreign investors, especially if industrial countries are experiencing a recession. The influx of capital increases the liquidity of domestic banks and financial corporations thereby stimulating credit creation.

The central bank accumulates foreign exchange reserves and if it does not sterilise them, money supply increases. Since in emerging countries monetary institutions, the supervision of the banking system and the imposition of risk management rules are not fully developed, credits are often not directed to their best use. In addition, there is usually widespread corruption and nepotism.

Under globalisation, domestic financial markets and institutions should be safeguarded by appropriate reregulation, e.g. the Basle rules for risk management and bank supervision. In many emerging countries, speculative bubbles develop in the real estate and banking sector leading to steep price rises and a subsequent crash in those markets. This raises the number of bad credits that will not be repayed, leading to substantial losses for banks. As a consequence a large amount of bank deposits are withdrawn that cannot be backed by selling assets or calling back loans. Interest rates climb to high levels reflecting increased risks. Even if the central bank buys out some commercial banks, many of them have to be closed. With this course of events investors doubt that the government will maintain the peg of its currency. Pessimistic expectations lead them to buy foreign exchange at the fixed rate.

Another problem concerns the growing indebtedness of domestic firms and banks in foreign currency. There is a considerable danger that the elimination of the peg will substantially increase the amount of foreign currency debt and corresponding interest payments in domestic money. A buoyant demand for foreign exchange is very likely.

Most investors are short-sighted and look for speculative opportunities that are offered to them by portfolios of financial assets under global conditions. Since short-term funds can be easily invested and withdrawn this makes it very difficult for the government to defend its currency peg. Even slight signs of fear that a country might abandon its peg will trigger a speculative attack. This is a so-called (safe) one-way speculation.

\section{Different Ways to Peg a Currency}

Emerging countries have used different forms of pegs. A fixed peg against the US-dollar was chosen by East Asian countries such as Thailand, Indonesia, Malaysia, the Philippines, South Korea and Singapore before the currency crises of these countries in 1997/98. A crawling peg with pre-announced devaluation steps was used instead by Mexico and Brazil before the outbreak of their currency crises in 1995 and 1999 respectively. Other countries, e.g. Hong Kong and Argentina, adopted a currency board system vis-à-vis the US-dollar in 1983 and 1991 respectively. Dollarisation, with the US-dollar as legal tender, was chosen in 2000 by Ecuador in the aftermath of its currency crisis.

How do these pegs differ from each other and what implications do they have on the likelihood that a currency crisis could occur? Any kind of currency peg, even if the government is determined to defend it, can be reversed. We can distinguish between a free move to flexible exchange rates or one forced by heavy losses of foreign exchange reserves. However, dollarisation or membership of a currency union are only reversible at a very high cost. The different forms of a peg can be listed according to increasing commitments to bind the domestic currency to the reserve currency: crawling peg, fixed peg, currency board, currency union and dollarisation. In this order the credibility of the peg increases.

\section{Currency Boards}

A currency board is a monetary institution whose base money (Mo) has to be backed $100 \%$ by an international reserve currency. There is a fixed exchange rate between the domestic and the reserve currency. A currency board aims to reach full substitutability (convertibility) of these currencies in order to transfer the reputation of the reserve currency to the domestic one. Strict rules for monetary and fiscal policies are necessary to make this transfer possible. Discrete monetary measures or the financing of budget deficits by money creation must be excluded. In order to introduce a currency board, a sufficient amount of foreign money should be available. Although base money is backed $100 \%$ by foreign currency, this is not usually the case for extended money supplies such as M1 or M2 because of secondary money creation. Therefore a currency crisis may develop even in a country with a currency board. There are some disadvantages to a currency board system. It can neither make use of monetary policy, nor take on a "lender of last resort"-function and there is a substantial loss of seigniorage gains. With a currency board, procyclical behaviour is accentuated: during good times capital inflows increase, lower interest rates and initiate a 
boom; if economic conditions deteriorate or if pessimistic expectations of investors are self-fulfilling, capital flows are reversed and interest rates rise, thereby causing a recession. One would suppose that a currency board is less vulnerable to currency crisis than a simple fixed peg. However, the case of Argentina shows clearly that a currency board is not immune to crises.

\section{The Argentina Crisis}

When Argentina suffered from a hyperinflation that amounted to $5648 \%$ between June 1989 and June 1990, Carlos Menem's new goverment introduced a currency board in 1991 ( also called the convertibility plan) against the US-dollar with the parity 1 Peso $=1$ US\$. The money base was covered $100 \%$ by foreign exchange, gold, and dollar-denominated debt of the Argentinian state. The demanded percentage of foreign exchange, however, was only $66 \%$ although the actual coverage remained on a $95 \%$ level up to 1996. To maintain its currency board, Argentina had to pursue monetary and fiscal discipline. Financing public sector deficits by printing money was prohibited and the lender-of-last-resort function of the monetary authorities was curtailed. As a consequence, the inflation rate fell to $10 \%$ p.a. in 1993 (see Figure 1). Full convertibility of the peso was estab- lished for both current and capital transactions. This increased transparency in the economy and re-established investors' confidence as foreign exchange risk seemed to be absent.

The introduction of the currency board was coupled by the liberalisation of foreign trade, deregulation, privatisation and a reform of the financial system. A trade reform was pursued to reduce distortions and to integrate the economy with the world markets. Export tariffs and nontariff import barriers were almost eliminated by the end of 1991. With deregulation, the government abolished all price controls, removed barriers to entry in wholesale and retail trade and relaxed regulated access to professional services. From 1991-1994 the Argentinian government privatised some $90 \%$ of all state enterprises for the equivalent of more than US $\$ 20 \mathrm{bn}$. The privatisation brought about considerable gains in economic efficiency together with a reduction of employment in this sector. The transformation of the financial system improved banking and financial intermediation. In order to avoid financial crises, banks' reserve requirements and capitalisation ratios were lifted. Financial markets were liberalised, eliminating the discrimination of foreign investors, banks and firms. As a result of these reforms, real GDP-growth was $5 \%$ p.a. on the average during 1991-1998 (see Figure 1).

Figure 1

Inflation and Real GDP Growth in Argentinia

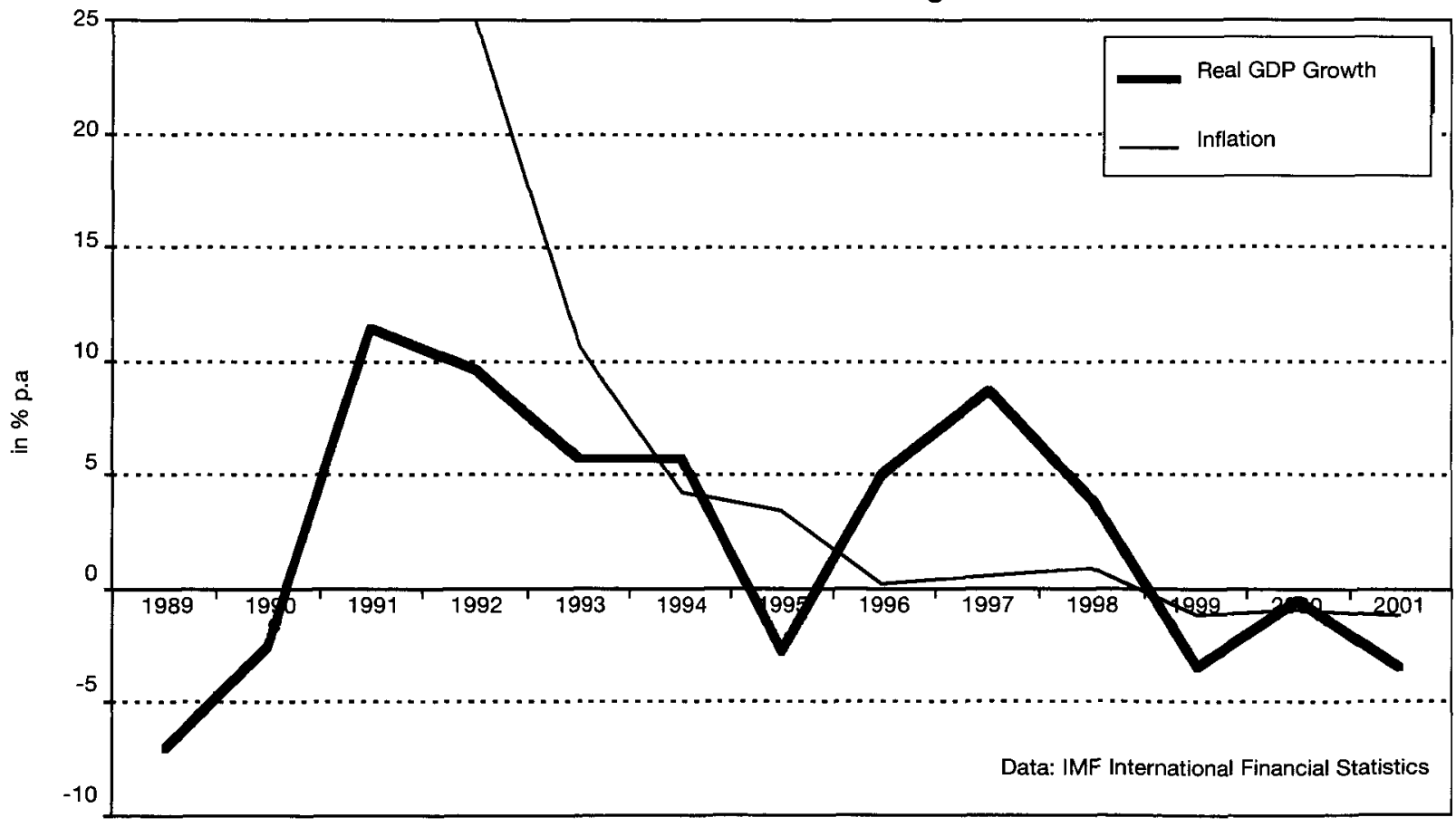


In spite of the strong reduction of Argentinian inflation, it remained significantly higher than that of its main trading partners. Together with an extended period of revaluation of the dollar against most other currencies, the fixed peg to the dollar led to a real overvaluation of the peso that substantially reduced Argentina's competitiveness. Imports soared while exports grew less, leading to trade balance and current account deficits (see Figure 2). In order to finance these deficits Argentina accumulated external debt.

While the budget deficit remained low up to 1992 due to privatisation gains, it has climbed strongly since then (see Figure 2). From 1992 to 1998 public debts doubled. The deterioration of public finance was reinforced by a change in the social security system where a complementary private capitalised scheme was introduced that led to a substantial reduction in entrepreneurs' contributions. Although this reform resulted in a reduction in the future liabilities of the public system, the budget deficit rose during the transition period by an amount equal to the contributions shifted to the private pension system. The deficit was aggravated by tax evasion of firms and widespread corruption. Government spending increased mainly at the provincial level. The provincial governments were spending far more than they were collecting in taxes. Much of this spending concerned government payrolls. In spite of privatisation, in some provinces more than $60 \%$ of the labour force was employed in the public sector. This resulted in distortions on the labour market. Because of the currency board, Argentina could not finance its budget deficit by printing money but only by credits via financial markets that would exert fiscal discipline on the government. Increasing indebtedness led to rising interest rates and higher debt service.

The dollar peg and favourable perspectives of investors caused a substantial inflow of (mainly shortterm) capital. This helped to overcome the capital shortage in financing economic growth. Dollar credits were increasingly demanded by the government, domestic private firms and banks because of lower interest rates abroad. In emerging countries financing mainly takes the form of bank credits rather than financial market instruments.

As of 1998 Argentina experienced a severe recession that was accompanied by increasing unemployment. The real overvaluation of the peso and the substantial devaluation of its main trading partners' currencies (e.g. the Brasilian real devaluated about $50 \%$ against the dollar in 1999) deteriorated Argentina's competitiveness, which reduced

Figure 2

Budget and Current Account Deficits in \% of GDP in Argentina

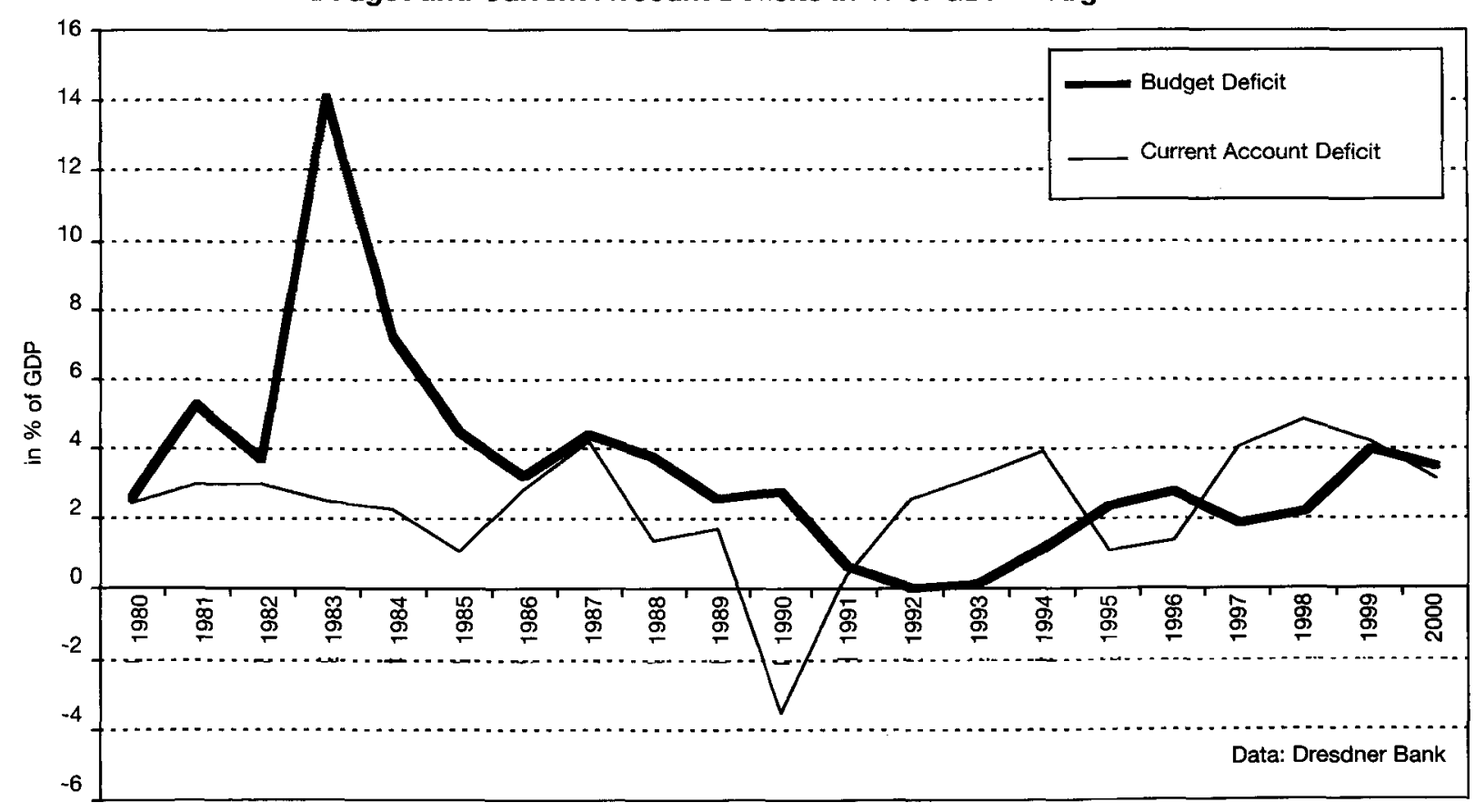


aggregate demand. Growing budget deficits and high external debts led to a sharp rise in domestic interest rates, reflecting higher risk premiums. This had a negative effect on private investment.

In order to maintain the fixed peg it was necessary to pursue fiscal discipline. Unfortunately, restrictive fiscal measures aggravated the recession, substantially reducing real GDP-growth and leading to deflation. While under flexible exchange rates competitiveness can be restored by devaluation without harm (with the exception of cumulative devaluations) with a fixed peg it can only be improved through the painful process of deflation. The IMF supported Argentina's austere fiscal policy measures in spite of its severe economic consequences.

Facing the downward spiral of the Argentinian economy, the IMF and some industrial countries agreed to provide a rescue package of US\$ $42 \mathrm{bn}$. in December 2000. Payments would only be effected if progress was made in economic policy according to predetermined requirements. Sticking to the fixed peg, Argentina was obliged to follow a strict fiscal regime that deepened its recession. Because of growing budget imbalances the de la Rúa government introduced the "zero-deficit" policy in July 2001. Government expenses should be brought into line with tax receipts - yet with decreasing taxes owing to recession it became increasingly difficult to reduce public expenditures. Through restrictive policy, aggregate demand and supply were further reduced. In order to limit interest payments and repayments on public debt, the government offered its domestic creditors to exchange obligations for longer-term credits with reduced interest rates and to guarantee these credits by tax receipts. Since the price of government obligations had already been adjusted to $50 \%$ of its nominal value by the market, most creditors accepted that offer. The government planned to negotiate the restructuring of debt held by foreign creditors in a similar way.

Because of the protracted recession, growing interest rates and the reluctance of banks to renew or to grant additional credits, many firms were pushed into default, thereby aggravating unemployment. Together with delayed payments of salaries and reduced welfare payments poverty grew substantially.

Figure 3

Different Stages of the Argentina Crisis

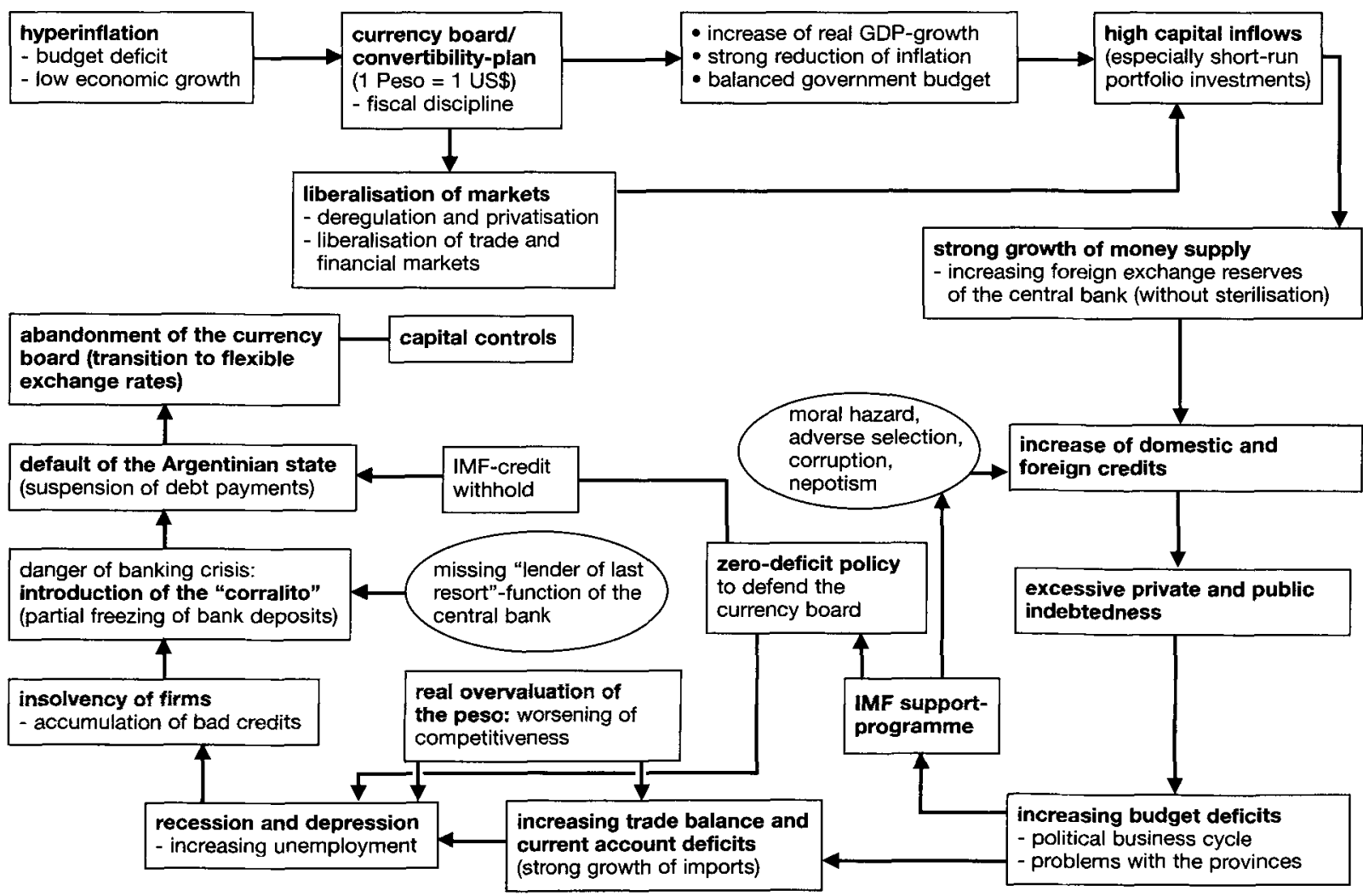


In spite of the sound banking structure and high reserves to cope with financial difficulties, the credit crunch and pessimistic expectations induced the public increasingly to withdraw bank deposits (the total amount being some 65 bn. pesos) during 2001. In order to avoid illiquidity and insolvency of the banking system, the government decided in December 2001 to limit the withdrawal of deposits to 1000 pesos per month and person. This measure of protection against bank runs was called "corralito". In addition, the government limited the amount of dollars to be taken out of the country, thereby implementing capital controls to guarantee the fixed peg.

These policy measures, together with the IMF's refusal to pay a credit share of US\$1.3 bn. in early December 2001, provoked heavy protests, plundering and vandalism in Argentina. As a consequence, the minister of economics Domingo Cavallo and president Fernando de la Rúa resigned. Within two weeks five presidents were in office. Finally Eduardo Duhalde was elected president on January 1, 2002. While his predecessors defended the fixed parity, Duhalde decided on January 5 to devalue the peso by $29 \%$ against the dollar in order to improve the country's competitiveness. The new parity, 1 US $\$=1.4$ peso, was applied to commercial trade, while the freemarket exchange rate plunged to 1.7 peso per US\$. The strong devaluation of the peso, together with the freezing of the government's dollar debts, concluded the country's default. After some weeks of a split exchange rate the "free" peso devalued more than $55 \%$ against the dollar ( 1 US $\$=2.3$ peso). On February 11 the government decided to float the peso, maintaining the "corralito" and the capital restrictions in order not to cause a disruption of the financial system. These measures were intended to reduce the likelihood of speculative attacks on the peso. The central bank's foreign exchange reserves (which amounted to US\$17 bn.) could be used to stabilise the peso. Private dollar debts were further allowed to be converted to equal amounts in pesos without limitation.

Figure 3 shows the different phases of the Argentina crisis including economic factors and policy measures. The dynamic structure and feed-backs are outlined without stressing strict causality.

\section{Conclusion}

The introduction of the currency board certainly had merits for bringing down hyperinflation, restoring the confidence of investors and promoting economic growth. The liberalisation and deregulation of local markets favoured massive inflow of (especially shortterm) foreign capital. However, the real overvaluation of the peso diminished competitiveness, which led to rising current account deficits. As budget deficits increased, austere fiscal programmes demanded by the IMF were applied. Severe recession and deflation resulted in a economic downturn. To stop that process it would have been necessary to allow for some flexibility of the exchange rate at an earlier point in time.

The elimination of the currency board, the devaluation and the subsequent floating of the peso certainly came too late. If a country is already experiencing a severe crisis, such measures may have a negative repercussion effect. With increased uncertainty, economic agents are more sceptical about the course of economic policy and are reluctant to invest. Capital controls impede necessary capital inflows and aggravate economic development. The confidence of investors is not easy to restore, especially with regard to the country's default. Unfortunately, so far there are no default rules for countries that could bring about an ordered procedure analogous to the private sector. In addition, there is a danger of imported inflation in spite of free capacities in industry.

Another possibility would have been to move straight away to dollarisation, since Argentina was already dollarised to a large extent. Such a transition could be effected by first devaluing the peso and then replacing pesos by dollars at the new exchange rate. However, this would presumably not have solved the problem of competitiveness in the longer run. Although the new stable currency would lead to lower interest rates, Argentina could no longer use monetary policy as a means of adjusting to specific economic changes. Nor could fiscal policy be handled independently. There would be a substantial loss of seigniority gains. The value of external debts would not increase, with the exception of an initial effect. The danger of the country's default would have been reduced but not eliminated.

In general it is very difficult to judge future implications of such policy measures given the chaotic situation of the country. It is essential to reduce uncertainty and to restore confidence in Argentina. The crisis can only be conquered by changing domestic structures, improving institutions and reducing corruption, together with international help. The lack of reaction by the IMF shows that economic solutions are not easy to find in a global context. 